\title{
ECONOMIC REFORMATION OF UKRAINE: Historical AND Legal ASPECTS
}

\section{Svitlana Khomyachenko ${ }^{1}$, Sergey Yuldashev ${ }^{2}$}

\begin{abstract}
The purpose of this study is to analyze economic reforms conducted in Ukraine during the period of the state's independence. And also to identify, with the help of scientific tools system analysis, management problems in the economy, their diagnosis, identification of the consequences that led to these problems, and ways development (at conceptual level) for their solving. The authors of the article proposed the concept of reforms in Ukraine. At the heart of the concept is the administrative reform aimed at creating organizational conditions under which corruption in power is almost completely neutralized. It is argued that such conditions are created by ensuring transparency, introduction of new information technologies, and minimizing the proportion of the so-called "human factor". Within the framework of the innovative project (model) of economic management, it is envisaged to redistribute central power between the central apparatus of economic management, local authorities and the non-state sector.
\end{abstract}

\section{Keywords}

Transformations, Reforms, Law, Public Administration

\section{Introduction}

In Ukraine there have been significant economic and social transformations in recent decades. While considering transformations in the economy, it should be noted that economic reforms, conducted in Ukraine, were mostly bureaucratic and formal. These reforms caused the country's plundering, theft of its assets, and the national wealth of the country. In addition, past years of Ukraine's independence have not been used to restructure the economy and translate it into an investment-innovative development path. Some attempts to set and resolve such tasks have come across private interests and have been lost in a general disorderly movement.

\footnotetext{
${ }^{1}$ National University of Life and Environmental Sciences of Ukraine Heroyiv Oborony st., 15, 03041, Kyiv, Ukraine. E-mail: arturmark@ukr.net.

${ }^{2}$ National University of Aviation. Kyiv, Ukraine. E-mail: youldashev_a@ukr.net.
} 
The main reason for the inefficiency of social change was the creation of a system of political power dominated by influential groups and a competitive struggle between them, the transformation of state bodies into a means of obtaining specific objectives. Such character of organization of the government caused explosion of corruption, spread of shadow and even criminal processes in economy and management, provoked fundamental destruction of the value structure of Ukrainian society. ${ }^{3}$ Despite notable positive changes made as a result of reforms, state management of economic processes in Ukraine under market conditions is in the stage of improvement, in particular, its further development is ongoing. In order to ensure the formation of a democratic society, the main task of reformation should be building of an effective system of public administration, which is possible only if the branches of power that meet the standards of a democratic rule of law with a socially oriented market economy are interacting.

In this context, there is a need for a comprehensive study of the main stages of economic reform in the history of independent Ukraine. Identify problems and weaknesses in its implementation and develop a concept of administrative reform.

The aforementioned concept can be interpreted as a possible alternative to solving the most important state problem of the progressive economic and technological backwardness of Ukraine from the highly developed states (with all the ensuing negative consequences of economic and social character (low standard of living, migration of part of the ablebodied population, declining to other countries for employment, "brain drain") and political character (threat to sovereignty, national security, territorial integrity of Ukraine).

This model correlates with the relevant European and American models, within which think tanks (the intellectual, think tanks) operate very effectively, ensuring effective decision making.

The basic methodology of the study is system analysis (SA), a problem-oriented approach. The following stages are the basis of this methodology implementation: identification of problems (as the difference between the desired and the actual), their analysis, diagnostics (identification of the causes of problems) preparation of alternatives for their solution; methods of analysis and forecasting, modelling and structuring, expert assessments, etc. Methods of this study include historical and analytical, sociological methods, a method of expert assessments.

\section{Main stages of reforming in the history of independent Ukraine}

Let us briefly consider main stages of reforming in the history of independent Ukraine. Over the past 20 years of the state independence, numerous attempts have been made to announce loud breakthrough reforms; large-scale projects on modernization were declared. Politicians, acting authorities did it exclusively for political purposes, striving for any price to remain in power, plunder as much as possible, and export abroad, in offshore, more. Lists of this kind of declarative reforms, with attempts to analyze, are contained in the

\footnotetext{
${ }^{3}$ Heitz (2009).
} 
articles of A. Galchynsky ${ }^{4}$, O. Valevsky ${ }^{5}$ and others. If you briefly touch on the history of reforms (in the bulk of the declarative, bureaucratic nature), then among the first ones should be those that occurred during the first cadence of President Kuchma in 1994-1999. The main slogans under which the reforms of this period were made (in fact, masked) were the tasks of liberalization in the economic sphere, stopping the economic downturn that began after the collapse of the USSR, optimization of state institutions in accordance with post-Soviet market principles. Yes, it is the optimization (which is still under way) instead of their full reorganization. A prominent program document of the period that represented the strategy of reforms can be considered L. Kuchma's speech in the Verkhovna Rada of Ukraine "By radical reforms" (1994). The degree of bureaucracy of a phenomenon is determined by its deviation from the actions that actually occur.

During 1994-1999, along with the holding of the so-called "small privatization", introduction of the national currency, formation of supposedly market institutions, creation of state institutions in accordance with the new Constitution of 1996, there was a division of state and redistribution of already distributed assets (industries) of the Ukrainian industry, banking institutions, etc. Economic downturn in the country (as well as the standard of living of ordinary citizens) continued; there was a rapid stratification in the society, a small group of people, mostly associated with power, including criminal, has increased its wealth and not always legitimately.

In the continuation of the second term of the presidency of L. Kuchma (2000-2004) due to the privatization of large industrial enterprises, formation of a powerful oligarchy, full approximation of business to power, the merger of these spheres took place. During this period, main oligarchic financial-industrial groups were also formed.

Following O. L. Valevsky under the "oligarchy", we will mean not just big capital, but those financial and industrial groups that: 1) occupy a monopoly position in certain branches of the economy; 2) have sufficient resources to nominate and win their presidential candidates; 3) own certain political forces that are capable of defeating in parliamentary and local elections; 4) have their quota of positions in the government and in local executive bodies; 5) control media that are capable of conducting information campaigns on a nationwide scale $^{6}$ (in our opinion, it should be added: 6) "privatized" certain budget items, budget streams. In addition, this sign is the main thing to which others, listed in clauses $1-5$, work). As a result, the state-oligarchic model, in which economic activity is inextricably linked with the political and state governance, is formed.

Among the program documents of this period, one can mention the message of the President of Ukraine to the Verkhovna Rada of Ukraine "European Choice. Conceptual Bases of the Strategy of Economic and Social Development of Ukraine for 2002-2011" (2001), where the tasks of the European integration of Ukraine were most systematically laid out. However, strengthening of the destructive influence of oligarchic capital on the state policy and the economy as a whole, internal political conflicts, deployment of a "cassette scandal", the murder of a journalist G. Gongadze, and others resulted in the

\footnotetext{
${ }^{4}$ Galchynsky (2011).

${ }^{5}$ Valevsky (2013).

${ }^{6}$ Valevsky (2011).
} 
fall of public trust in President Kuchma and his policies, which also did not contribute to the implementation of certain tasks.

The Orange Revolution, which aroused considerable interest of the European community in Ukraine, brought Ukraine the status of a market economy country. The Jackson-Vanik Amendment to the US Trade Act, which restricted trade with countries that impede emigration, and violated other human rights, was abolished. Ukraine joined the World Trade Organization. However, the potential of the hopes that arose after the Orange Revolution was not used to reform the country's economy. On the contrary, corruption was widespread in state policy, and the investment attractiveness of the country diminished. During the presidency of Yushchenko (2005-2010), for the most part, the authorities also declared the need for radical economic reforms. Among the documents of that time, in particular, the program "Ukrainian breakthrough", which was presented by Yulia Tymoshenko, should be noted. However, because of the monopolization of political and economic spheres by the oligarchy, inevitable personal and institutional conflicts in the power sector, the financial crisis of 2008, the reform work, as such, was not carried out.

During the presidency of Viktor Yanukovych and the political forces that supported him at the 2010 presidential election, the program "Prosperous Society, Competitive Economy, Effective State", in which the ways of reforming society were presented, was proclaimed. At the same time, the experience of implementing this program shows that it has its own disadvantages that were characteristic of all previous reform projects, namely, the absence of real economic problems in the program. Since this is so, the stated goal did not meet the needs of correcting the distorted economy, and therefore the means were not suitable for the necessary reformation.

The economic crisis of 2008 convincingly demonstrated that the export-raw material model of the economy with oligarchic clans, which occupy a monopolistic position in certain sectors of the economy, was extremely unstable and not capable of ensuring neither sustainable economic development of Ukraine, nor the preservation of the potential that had been achieved in the past period.

As for the post-revolutionary period, the period that began after the Revolution of Dignity (from 2014 to the present time), no meaningful nationwide programs have been developed. We have only a bunch of "Strategies" for the development of individual branches of the economy. Regarding their value, then the critical one expressed in relation to the abovementioned programs also applies to the approved "Strategies".

In our opinion, an important problem of the governance is the domination of external influence on the implementation of reforms. Practice has shown that socially significant reforms were implemented under the pressure from external actors, in particular, international financial institutions. This is especially evident in the pension reform (it is also more or less related to the economy) and the desire to deprive the state of social guarantees to the population.

In addition, understanding in Ukraine of some phenomena, connected with the market economy, (as it does not look strange), should be related to managerial problems. It is necessary to reconsider certain stereotypes of views on certain economic relations that have taken root in our consciousness. First, the view that the private property is a priori 
more effective than the state. Even a comparison of the Soviet socialist (exclusively state) property with a private one in present-day Ukraine breaks down this stereotype (more specifically, this thesis will be disclosed below). Is it possible to compare order and chaos, focus on state and selfish, private interests?

If you take Western countries with a developed market economy to compare, then there is a bunch of examples of effective enterprises of the state ownership. In addition, we forgot, and more precisely, most likely, deliberately eradicated from the legal field of such a category as a collective property (not without the help of our oligarchs and some foreign philanthropists, perhaps the thieves from Ukraine, who migrated abroad).

Secondly, one should refuse understanding of the essence of privatization. Privatization should help increase the competitiveness and efficiency of the economy, and not only personal enrichment, as it has been silently rooted in our Ukrainian mentality.

Thirdly. Developers of reforms must take into consideration specifics of the political situation, features of the traditions of the population, the level of tendency to cause corruption in the mass consciousness (voting for buckwheat is exclusively a post-Soviet tradition inherent in a significant part of the Ukrainian population), the scale of the corruption spread, the technological and intellectual potential of the society, etc.

Fourthly. Domestic reformers continue the standards of reforms that were carried out in the socialist past and which have always been counted on the stereotype, according to which the proposed programs should be perceived by citizens solely as a way to a bright (communist) future. One of the myths of that time sounded like a goal "catch up and overtake (the USA)". At the same time, the West and America were always "rotten", such as "standing on the edge of the abyss". By the way, one can recall different jokes of that time: "Communism is a horizon, the closer you approach it, the further it goes away", "Catch up and overcome America, standing on the edge of the abyss", and so on.

Programs of submitted reforms did not contain even the task of creating a concrete, effective mechanism, which would guarantee their implementation, for example, made it impossible to obtain privileges and profits by the implementation of the current "management", not to mention the modernization of certain business groups or social strata. Targeting of reforms to increase privileges and profits by oligarchic clans at the expense of further robbery of the population (the electorate) is, in general, blasphemy and looting.

Namely, such actions are viewed in the appointments of "underbosses" in all sectors of the economy, bringing together the most fat, affectionate ministries and departments of the most profitable sectors under the guise of a trustee. This, for example, is the merger of the State Tax Service of Ukraine and the State Customs Service of Ukraine into the Ministry of Inland Revenues of Ukraine (Mindokhodiv), which was created in the government of Azarov in December 2012; creation of the Ministry of Infrastructure, which also united the most corruptly attractive transport industries (rail, air, road, river, sea transport). The essence of such a "reform", which was carried out under the slogans "change", "optimization" (Presidential Decrees "On Changes in the Structure of Central Executive Authorities", "On the Optimization of the System of Central Executive Authorities", etc.). In fact, it was an association under one watchful eye of the most trusted people, in order to establish total control over financial budget flows. 
Regarding current problems of Ukraine in the sphere of economy. All of them - in the management of it. One of the most important administrative problems is the decline of the national economy, impoverishment of ordinary citizens, merging authority with business, oligarchic essence of the state, appropriation of a significant part of financial, budget flows, corruption. Detection of the indicated problems by means of the system analysis, their diagnosis (establishment of the causes of occurrence), as well as the definition of solutions to problems (at the conceptual level) - appears to be extremely important.

It should be noted that in our sciences (economic, political science, legal, state administration, etc.) we do not often associate specific administrative problems, decline of the national economy, impoverishment of ordinary citizens with the organization of governance - the oligarchic nature of the state, corruption. Modern research on the solution of these problems, with the use of scientific tools - the system analysis - is not conducted at all. Since this is the case, then these problems continue to exist, and solutions to them are not offered. Conspiracy approaches, which are demonstrated mainly by political scientists are said to "no need to count".

The essence of change in various spheres of society modern research theorists of management see in the transition to decentralization (instead of the former concentration); variety (diversity of goods, services, cultural pluralism) instead of the former unification; "plastic" management structures instead of hard confrontation, etc.

"Post-industrial society", says one of the many textbooks on state governance, is a stage of social development that replaces state-monopoly industrial society. It is characterized by a reorientation of the economy from commodity to service (development of "civilization of services": education, science, advertising, tourism, etc.), change in the social structure of the society (class division gives way to professionalism); moving knowledge centres, which have a decisive influence on the strategy of the society development, to universities; domination of the main product of production, creation of new intellectual technologies, globalization of social and informational space.

At what stage is Ukraine currently in this "kaleidoscope" - as a rule, nothing is said. Meanwhile, it is the students who need to know not only the patterns of such social transformations, but also be able to identify specific problems, analyze actual reality. And it, relating Ukraine, is, in our opinion, that starting from 1991, there was a transition from the imperial militarist-bureaucratic state with elements of sociality (in modern terms - "state-monopolistic industrial society") to a state with a fully controlled by oligarchs economy, monopolized in their favour branches of Ukrainian industry(by the textbook "post-industrial (post-modern) society".

Unless you reveal a specific nature of the object of knowledge, the unknowable "thing in itself", which Kant says in his "Critique of Pure Reason" "7 about, will never become a thing for all. Namely, this (to turn the "thing in itself" into a thing for all) seems to be the goal, which faces the educational process at universities, without which implementation, there will be no transition from the world of abstractions, apologetic praise of reality (and this took place in the recent socialist past) - to an adequate perception of it for the subsequent

\footnotetext{
${ }^{7}$ Kant (1994).
} 
constructive transformation. The latter, in relation to the topic of our study, should be radical changes in the executive bureaucracy, the implementation of which is delayed and blocked by "political elites", which for decades parasitize on the remains of the critically robbed state.

As it was noted, in the first stage of this study, through the system analysis, there are managerial (administrative and legal) problems in the Ukrainian economy, the consequence of which is the decline of the national economy, impoverishment of ordinary citizens, merging power with business, oligarchic essence of the state, appropriation of a large part of the financial, budgetary, corruption by ruling organized crime groups (OCG).

Within the system analysis, a problem-oriented approach is used, which consists not only in identifying the problem, but also in its structuring (building the "tree" of the problems), analysis, determining the causes of the problem (its components), as well as developing alternative solutions to the problem (the development of a list of measures, elaboration of a targeted integrated program for resolution, etc.).

\section{Analysis of the revealed problems}

Let us turn to the analysis of the revealed problems. It was noted above that in our country, in almost all spheres of life, significant changes have taken place in the last three decades. Not without crises, both economic and political.

The Orange Revolution of 2004, the Revolution of Dignity of 2014 has become an important milestone in the formation of the Ukrainian nation. At the same time, the connection of the protracted economic crisis, in which Ukraine is located, with a total split-up of its economy, is relatively rarely highlighted. The same is related also to the fact, that political and business barons, fearing to lose the looted assets, uncontrolled access to financial flows - will make a fierce resistance to real reforms. It is determined (for the time being, mainly for political purposes) that corruption is a very common problem in Ukraine.

As it is rightly believed by Lipinsky, D. A., Musatkina, A. A. "Corruption of domestic and international officials impedes market freedom, fair competition and the restriction of monopolistic activity. The most dangerous part of corruption - the elite, transnational and political - does not exist in the form of the usual transfer of money or other property directly to an official. It disguises itself as various kinds of transactions, provision of benefits and advantages to officials, often accompanied by banking operations, which, in turn, are aimed at giving legitimate status to the received remuneration. Domestic and international organizations are involved in corruption transactions". ${ }^{8}$

Its large size is also mentioned, including in foreign sources. In the Corruption Perceptions Index, the international organization Transparency International systematically allocates space to Ukraine in the last thirty of the 180 researching countries, (as a rule, we are along with Iran and Myanmar). Some international auditing companies (including Ernst \& Young) put Ukraine in the top three corrupt countries in line with Colombia and Brazil,

${ }^{8}$ Lipinsky, Musatkina (2019). 
etc. We remember how at one time the United States diplomatic service described Ukraine during the presidency of Leonid Kuchma and Viktor Yushchenko as klyptocracy.

Corruption has gained widespread scope in the field of geological exploration and use of subsoil, which significantly destroys the country's energy security. "Corruption in Dezhgeonadra blocks energy independence of Ukraine", was written in foreign media. ${ }^{9}$ The issue of corruption in the leadership of the State Service for Geology and Subsoil of Ukraine in Ukraine was considered even in the Congress of the United States of America, where congressional representatives called the sum of rollback by obtaining licenses for oil and gas production. This is reported by the French edition of Guardian. ${ }^{10}$ Recently, they are actively writing about the revealed corruption in the field of defence, fairly comparing the theft of appropriate state funds with looting, etc.

At the same time, speaking of corruption, the Ukrainian authorities, politicians in every way try to inflate ordinary citizens and the international community, nodding ("translating" arrows) on corruption in the courts, the prosecutor's office. Moreover, they succeed. They speak about the plundering of budget funds at higher levels of government much less than about corruption in the courts. About the theft of material assets of the country, national wealth is said even less. Meanwhile, the fact that the country is in an economic disaster is, undoubtedly, a fact, and the guilty are those who were or are in power.

Drachkovich M. V. notes "Elites have privileges on resources (labour, land, capital, entrepreneurship) and appropriate economic rents. The dominant coalition and the elite are closely related, and the exchange between them is based on personal ties. This undermines public choice, competition and development, becoming a source of destabilization of the economy and society. Manifestation of violence in society shows the close relationship of economic and political behaviour, in which the latter dominates". 11 The size of the economic catastrophe in Ukraine corresponds to the degree of toxicity for the country of each of its leaders - the corresponding officials. We will illustrate the above. The Ukrainian SSR, at the time of the withdrawal from the imperial alliance, when among its leaders it was not yet fashionable to steal billions from the state treasury, in its economic development took the 2 nd place. Social sphere was, albeit one-sided, but also quite developed, medicine and education - free (and, on a very good level).

Almost free public transport, housing and communal services, including gas, electricity. At the same time, tariffs, if were not lowered, then in any case, practically were not felt! In the past, the oil refining industry worked well. The capacity of five Ukrainian refineries (as of 1991) amounted to more than 50 million tons of raw materials per year. This is more than was produced by all the oil refineries of the Warsaw Treaty countries together! Small (if not meagre) prices were fixed for gasoline, fuel and lubricants. Truck drivers of state transport fleets often pour gasoline directly into the ground. Now almost all refineries are idle. We buy gasoline, diesel fuel in Russia, Belarus; we make deliveries from such countries as Turkmenistan, Kazakhstan, Azerbaijan, Romania, and Israel. The same thing is with electricity. In Ukraine, it was produced with great surplus. For a symbolic price,

\footnotetext{
${ }^{9}$ Wschodnik. pl. (2017).

${ }^{10}$ Paris Guardian (2017).

${ }^{11}$ Drachkovich (2019).
} 
the USSR gave an oversupply to "fraternal" countries. However, what is happening now in the energy sector of Ukraine is a colossal energy threat to the national security of the country.

In relation to consumer goods and products. Prices were regulated "from above", were tightly controlled and for most goods and products were quite low. Art and culture was available for everyone; classes in all arts, sports - free. Conditions for classes were quite decent. Holiday homes, well-off sanatoria - often at the expense of trade unions. One should pay nothing. Corruption in power, in courts - practically none. If you do not take into consideration annual trips of the heads of republican ministries to Moscow for "knocking out" funds for the functioning of the industry. Nobody could think about theft from the budget. True, the country was losing on the so-called "smugglers" - massive petty embezzlement of insignificant material values by workers from their companies. On a countrywide scale, losses accounted for up to $5 \%$ of the gross product.

Sometimes (quite rarely) cases of so-called tsekhovik - underground entrepreneurs or speculators arose. Taboo was enforced for all this. Another thing is that the available scientific and technical potential was not used efficiently. The blame for this was enormous military spending, confrontation of the USSR with all the countries of the West, direction to the world advantage that was implemented, including and by providing generous "fraternal" aid to various clicks for the advancement of socialist "ideals", recruited agents for public office in these countries. To impose socialist ideals, push, as someone spoke perfectly, - "bullshit" (unlike democratic values) - always cost expensive.

Militarism of the USSR, enormous military spending, its focus on continuous improvement of its geopolitical influence in the world (Russia continues to do this now), support for "friendly" regulations, plus socialist "cost" production, as well as a tight veto on private (and for any) entrepreneurship - all this, of course, significantly impeded the development of the economy, lowered the potentially high potential of socialism in the development of the social sphere (that is, we see, on the one hand, the order and cohesion, and on the other, the suppression of opportunities exclusively for political purposes).

But the middle level - the maximum that the Soviet socialist administrative-distributive system could submit - has been achieved. The people paid for it as a general labour duty, as well as that they lived in a constant state of lies, fear and their own hypocrisy; they paid their non-freedom in everything, including in creativity.

At the same time, the scientific and technical potential of the economy of the Ukrainian SSR was rather high, it equalled almost the potential of Italy, surpassed the economic potential of Poland. With the departure of the USSR, independence not only from Moscow, but also from its people all the accumulated for many decades has been smuggled ("captured"), looted, stolen. The most powerful, profitable industries were handed out by the second president of Ukraine to five or six families.

Transport, in particular, the Black Sea Shipping and Passenger Fleet, which held the 11th position in the world in its potential and made Ukraine a great sea state, began to be sold, stolen quickly at the time of the first president.

A catastrophic situation has occurred in the area of passenger and cargo traffic on inland waterways. The number of vessels under the State flag of Ukraine has decreased (in 
comparison with 1991) more than 20 times. The catastrophic decline was observed in related industries, including in shipbuilding. At the time of the separation from the USSR, in Ukraine there were 10 large shipyards and several dozen shipbuilding factories. Aircraft carriers, submarines and other ships of different classes were built. Today, almost all of them are idle.

The same situation occurred in aircraft engineering and rocket construction. The revival of shipbuilding, as well as the entire cargo and passenger fleet of the country, is a national issue. They tried to cover all this plunder under the nationwide privatization of state enterprises, which in Ukraine began in 1992 under the slogans of denationalization of property. In 1993, people first heard about privatization vouchers, which they could receive in Oshchadbank and become the owner of one fifty two-millionth part of the national wealth. The government estimated the property of state enterprises in the amount of more than 520 trillion rubles, that is, in 1993, one voucher cost 10 million 50 thousand rubles. However, by the end of the year, this money has turned into nothing due to multiple inflation.

The population was deceived. You can imagine how much we had all, how many lost; how toxic was the board and how much the population degenerated and the authorities, on the contrary, enriched. After all, the wealth, like the amount of water on the Earth, is also a constant value - when somewhere it becomes less - for example, in the budget of the country, then in another place, the wealth, respectively, becomes more - on overseas accounts, there are super luxurious palaces, yachts, planes...

Regarding the problem of corruption, which is recognized as the most widespread economic problem in Ukraine. In our opinion, ordinary Ukrainians and the world community are misleading about this issue. There is no such big problem with corruption in Ukraine, in particular, judicial, as all politicians and those who are in power try to persuade us all. The fact is that we silently mention the theft of budget money to corruption. However, this is not corruption.

According to the law, corruption is "the use by a person given to it authority and related capabilities in order to obtain an unlawful benefit". ${ }^{12}$

Theft from the budget is not directly criminalized (for "non-purposeful" use of budgetary funds, not criminal, but administrative responsibility is provided).

At the same time, it is theft from the budget, the appropriation of the profit of state enterprises, for example, by concluding (fictitious, by their very nature) economic legal agreements - much (by one order more) dangerous to the country than any corruption. The latter is in many countries of the world, moreover, it is possible that it is in even more volumes than in Ukraine. For example, in the Pentagon (based on the absolute budget size) corruption risks are much higher than in the Ministry of Defence of Ukraine. But, everything is transparent there, unlike in the Ministry of Defence, Ukroboronprom of Ukraine. The corruption scandal that broke out there recently might have cost the presidency.

${ }^{12}$ Law of Ukraine (2014). 
Unfortunately, in our country the exposure of corruption in this as in other areas is not used to fight it, but only for political purposes, political struggle. There is also customs and judicial corruption in many countries. But they live with it and... thrive. Perhaps we would have prospered, if not for the plundering of the budget and the appropriation of profits of the public sector.

However, almost half of the budget of Ukraine (in the speeches of deputies the figure is more than $40 \%$ ) is plundered annually and goes to offshore. Nobody calculated what amounts are left in private hands through the appropriation of profits of state enterprises, say, a year. According to our data, this figure may exceed the annual budget. It is no accident that the overwhelming majority of them are unprofitable.

\section{Ways to overcome administrative problems of the Ukrainian economy}

Regarding the ways to overcome these (managerial) problems of the Ukrainian economy. To answer this question, one must determine the reasons for its occurrence. Regarding corruption (thefts from the budget, appropriation of profits of state enterprises), we distinguish these two reasons.

The first reason for thefts from the budget, corruption - the so-called "human factor" - the sinful nature of a man. We all are sinners, with human weaknesses, greed for money and the thirst for power. A man is sinful by its nature. At the same time, in the course of the man's evolution, its sinful heredity gets increasingly disgusting forms. After the analysis of this reason for thefts of the budget, corruption, two important conclusions arise. First, in no way it does not matter what kind of person we choose to power, it does not matter - a "new" or "old" person. It does not matter and their geographical origin (Ukrainians, foreigners). The main thing is that these are people, with all their human weaknesses. The fact that foreigners "all human is also not alien" could easily be verified when the authorities in Ukraine invited citizens of other countries. Being at home in the Motherland, perhaps, moral standards, they immediately became as if our corrupt (thieves) here. That is, assignment to a position, as well as elections (of the president, deputies), do not make such important significance, which is provided to them. Altruists are not so much also in the oligarchic state, "the enemy will not go through". Therefore, it is useless to hope for the arrival of an honest, "good king".

Elections are only a way (in our country, it is extremely expensive) to give the population, the electorate an opportunity to "blow off steam", not bringing people to other, radical ways of expressing their will, demonstrating their attitude to the current government. In addition, with regard to the appointments, the "undercurrent" "share-out" of ministries and departments, all posts are distributed well before the end of the election. Sometimes they cannot agree in any way after the elections, the parliament for a definite time (sometimes, quite long) is not able start working. It is at this time that the hot and violent battles between "political forces" continue, but not for ideological, but for material values. Those who have received many "fat pieces" form a coalition (they have so far what to divide, therefore, the coalition is "broad"), and deprived form the "opposition". 
The second reason for thefts from the budget, corruption. We do not have a system of checks and balances, which should be embedded in the organization of the management of the economy, its branches. In democratic countries, this system functions successfully. It is aimed at countering, neutralizing the "human factor", which was discussed above. In other words, humanity (its civilized, democratic part) has invented a special organization - special organizational conditions that significantly reduce the possibility of financial abuse in the government system. Americans consider such management system good, in which even the most mediocre manager (read, corrupt) cannot cause a system some great harm. We do not have such a system. Why? Because we inherited the old, control system, the state apparatus of the socialist past, the communist regime. Its essence was the focus of activities not to meet the needs of the population, the growth of people's wellbeing (although these goals were declared), but the maintenance of the world advantage of the USSR, continuous improvement of its geopolitical influence in the world. The administrative-distributive Soviet apparatus of the economy management had to ensure the implementation of militaristic tasks, quick complete rebuilding of the whole national economy of the country on military rails, clear record, monitoring and control of the entire able-bodied part of the population, its instant mobilization. The said apparatus carried out the named tasks with the help of directive-administrative methods, development and implementation of directives of the Central Committee of the CPSU, national plans for economic and social development. In addition, the administrative-distributive apparatus performed another important function - kept all the enterprises in the country (about 50 thousand) under its direction. However, when these tasks (functions) came to an end (that is, from the moment of the reconstruction in the USSR, withdrawal of Ukraine from the composition of the Russian Empire), and the enterprises, in the main mass, were privatized, that is, the object of management has also decreased - the leading administrative-distributive state apparatus has become a dilapidated superstructure that has no object of influence. Our leaders, without wise cunning, did not radically change this unit; its number has not decreased, but on the contrary - has increased. Instead, with the inherent Ukrainian mental spell, it quickly turned into a perfect means of stealing budget funds.

Therefore, when we read in some textbooks for students in administrative law that "The executive authorities carry out organized, purposeful activities aimed at... ensuring the proportional development of the Ukrainian economy. The Cabinet of Ministers of Ukraine in accordance with Art. 116 of the Constitution ${ }^{13}$ of Ukraine and Art. 2 of the Law of Ukraine 'On the Cabinet of Ministers of Ukraine'14 ensures state sovereignty and economic independence of Ukraine, conducting financial, pricing, investment and tax policy, equal conditions for the development of all forms of ownership... " - it's terrible, the hand, they say, "stretches to the pistol". Is almost complete destruction of the economy, carried out with the help of the executive authorities itself, is the implementation of "organizing, targeted action to ensure the proportional development of the economy"? And is the creation of a state (including state-guaranteed) Ukraine debt in the amount

\footnotetext{
13 Constitution Ukraine (1996).

${ }^{14}$ Law of Ukraine (2014).
} 
(at the end of 2018) of more than two trillion, continuous galloping rise in consumer prices, an extremely high level of the monopoly, brutal abuse of the oligarchs by their monopolistic position the "holding financial, pricing policies, creating equal conditions for the development of all forms of property"?

We should agree with Mirko Pecaric's position that "the success of any government and the implementation of its key strategies and reforms depend on such Centre that achieves this general goal through the coordination of ministries and other public agencies". ${ }^{15}$ In Ukraine, The Cabinet of Ministers should become the centre of Ukraine.

The question may arise why among the reasons for the existence of corruption they do not say anything about the work of law enforcement agencies, including newly created to fight offenders and corrupt people - NABU, Specialized Anti-Corruption Public Prosecution Office, National Agency for the Prevention of Corruption, now it is The State Bureau of Investigations? Do they conduct, or rather, are these authorities in Ukraine capable of effectively combating corruption, theft from the budget, and the appropriation of stateowned enterprises? The answer is the following. Hoping this, or giving a positive answer to the question, we forget that in these new organs ordinary people work, and therefore they are sinful in their human nature. By giving a positive answer, we also proceed from the assumption that here in Ukraine there are no forces that can easily completely reformat the goals of the many punitive structures that have been created. For example, there is no force that could, instead of massacre corruptors, turn the existing set of punitive structures into a means of massacre with unwelcome thieves, who want to drag their favourite feeders of power. Those who give a positive answer come from the fact that one or another entity (organization, institution) built to combat crime, after a while, is not rebuilt in its opposite - the structure that exactly creates crimes ("crumbles" the shadow, forbidden business, criminals, steals their own budget funds, etc.). After all, according to the law of bureaucratic, which is created by one of the authors of this article, any phenomenon, any "positive" administratively formed social nature - without proper control and correction, subsequently becomes its opposite. Therefore, it is wrong to think that the means of combating corruption will not turn into its nursery. Moreover, the more powerful the punitive structure, the lush and juicy will be this nursery. One should not think that the existing mass of punitive structures would not tear one from the other "red meat", fight among themselves, fight, but not with corruption, but for the corrupt people themselves, for the opportunity to encourage them.

This situation is not inherent only us. One can recall the secret police, which Napoleon created in due time after the French Revolution (the end of the 18th century) to control the gendarmerie. Afterwards, he created the Fouche police to control the secret police, and then... all these three institutions have been penetrated by solid corruption, they say, to the "bone marrow".

And these processes are not isolated. The same was observed after the victory of the October Revolution of 1917. Do we need to draw parallels and corresponding figures about the Revolution of Dignity? Unlikely. It is clear. That is why we do not apply today

${ }^{15}$ Mirko Pecaric (2019). 
our newest law-enforcement structures to effective means of combating corruption. At the same time, there are ideas; we can offer a program for their real restructuring. However, this is the topic of a separate discussion. Returning to the second cause of the emergence of managerial problems in the Ukrainian economy (there is no system of checks and balances, which should be built into the organization of the management of the economy, its branches), we would like to note that eliminating this reason is a solution to the abovementioned managerial problems. A decision that will require its administrative and legal support - the administrative reform. During the years of Soviet power and independent Ukraine, there were dozens, many dozens of them. But they were all bureaucratic, that is, never solved the real problems of managing the economy.

In order to replace the central executive authorities, one of the authors of this article developed a system of organizational models for the coordination of economic activities of enterprises of the relevant branches on the economic management of them. Now corresponding projects are at the stage of their registration as objects of intellectual property. Introduction of the author's project will allow solving the existing managerial problems in the country's economy, ensuring a sharp increase in the welfare of ordinary citizens, significant economic growth; to stop the plundering of budget flows, separate business from power, and thus change the oligarchic nature of the state. At the same time, a sharp increase in the welfare of ordinary citizens (approximately, 8-10 times) will occur during the year from the moment of the project implementation. How will this happen? Firstly, any possibility of stealing the budget and profit from the state sector of the economy will be blocked. Secondly. Functioning of decision-making centres will be transparent, understandable and effective. This efficiency will be ensured through good economic governance - the choice of the best solution from the number of equal alternatives, which will be prepared not by officials (civil servants), but by creative teams of specialists, that will work on a competitive basis, as well as transparent selection of performers, public monitoring of financing and costs. Our calculations show that only overcoming possibilities of stealing the budget and profits from the state sector of the economy will increase the annual budget by 1,7 times. Reduction of officials by more than $60 \%$ (by the way, Ukraine by the number of civil servants per thousand people of the population now occupies the first place in the world, ahead of even Russia), as a result of involvement in the preparation of management decisions of non-government structures, will also save large amounts of money in the budget. In addition, finally, the budget is expected to increase by $200-250 \%$ precisely due to the sharp increase in the quality of economic decisions. These are rather even understated figures.

If we proceed from the undoubted advantage of the Ukrainian mentality in the world (we can prove that over the past decades, most of the world's "know-how" have been made by people from Ukraine), then the emphasis in these decisions should be made precisely on the latest technologies. Not to the agrarian sector, as is often offered. The world has found a competitive basis for an alternative to black earths with constant weather disasters - in Israel, the lack of humus is completely offset by the year round sun - several harvests per year; technologies for the production of agricultural products without land, etc. are being successfully developed. In addition, general, resources have long lost their former 
importance in the country's economic development. Capitalization of the Chinese-Internet companies Alibaba and Tensent cost about a trillion dollars. This is in excess of the cost of Gazprom and Rosneft - Russia's national pride. Moreover, this is despite the fact that technologies for the replacement of raw materials are developing at a crazy pace. That is why the answer to who and where of the body part will be in the future - will depend on this type of the proposed project.

Increase in the budget due to high-quality economic decisions -250 percent - is even a rather cautious figure. We slightly disagree with a prominent Ukrainian economist O. Okhrymenko, ${ }^{16}$ who believes that "Ukraine needs 180 years to reach the 2013 level". All of the above can be done in 2-3 years. And this is still modest. The Chinese for the year have raised 400 million people from the poverty. The world has not known such phenomena so far. And the "Ukrainian miracle" - is quite real (we prove it by calculations) (we prove it by calculations). As for social change, it is not only an increase 8-10 times in the welfare of ordinary citizens. It is also the creation of an honest and open economic competitive environment, eliminating the oligarchs from the control of the Ukrainian economy by technological means. This is the de-oligarchy of power. And it will happen due to the loss of power of its attractiveness. Control and balance. As people in the power of rulers, and the last in the power of the people. However, those who wish to become the supreme president, are disastrously few. So, with the loss by power of its attractiveness, it will be possible not only to get rid from the pastoralists among politicians, who now sufficient, but it will also lead to the separation of powers from business, the change of the oligarchic nature of the state.

\section{The reform concept}

The essence of our draft of the administrative reform lies in the following. Overdose of central authority (such as has continued to occur in the USSR) as the central apparatus for managing the economy, government bodies and the non-executive sector. This will be both an administrative reform and a territorial reform with the power decentralization.

Drafting complex management decisions should be outsourced to non-governmental entities. This model correlates with the relevant European and American models, within which think tanks (the intellectual, think tanks, and brain trusts) operate very effectively, that are business-minded, impartial, offer many original ideas, ensuring effective decisions. Thus, instead of mindlessly manipulating personnel in power (which, in our opinion, is a completely senseless exercise - to change "old" faces to "new" and vice versa), which now involves almost the whole country, and maybe even part of it of the world we offer a fundamentally different approach. It is that personnel, especially those with extensive professional experience, should be left alone, even declared a moratorium on their dismissal in connection with reform. Moreover, the "new" faces are usually greedier in budget theft than the "old" ones. Therefore, it is necessary to change not the people, but the organization of management itself, create such organizational conditions under which it becomes impossible to steal. This can be done by ensuring transparency, introduction

${ }^{16}$ Okhrymenko (2016). 
of new information technologies, and minimizing the proportion of the so-called "human factor". It is about designing a qualitatively different organization, a management system in which "investment nannies" will become unnecessary; a system that will be "sharpened" under effective management.

Transition to such a system is a prerequisite for a strong budget filling due to internal organizational reserves (only as a result of neutralizing corruption in the upper echelons of power, we will annually receive about $\$ 40$ billion; due to quality management -6 to 8 times more and that's not all), ensuring the independence of the state, withdrawing it from foreign influence, including the dependence on the IMF. The proposed experimental testing of the model was carried out by one of the authors of this article on the example of innovation and investment anti-corruption mechanism of subsoil use. ${ }^{17}$

Introduction of the administrative reform in our model will be accompanied by the restructuring of education and science, implementation of appropriate judicial reform and the reform of the law enforcement system.

The moratorium on the "updating" of law enforcement personnel, the judiciary and others is also at the heart of these reforms. Here too, all attention should be paid to the organizational conditions of decision-making (including judicial), ensuring their legitimacy, validity and fairness. All this will significantly increase the main economic indicators by orders of magnitude. There is no need to sell the latter - strategic businesses, land, legalize gambling, drugs, prostitution. We will not choose (at least for investments), but we will choose the best offers, we will produce the most effective economic decisions aimed at building Ukraine as an information society, an innovation hub, a knowledge society. The country from the poorest in Europe in two to three years will turn into the most successful with all social consequences, instead of centrifugal trends, the opposite will appear - the aspiration-centred ones, there will be a great inflow from abroad, and those will be not only Ukrainians. The same will be true of investments that go primarily to successful countries. Ukraine can become such a country.

\section{Conclusion}

One of the most important administrative (administrative and legal) problems in the economy of Ukraine is the decline of the national economy, impoverishment of ordinary citizens, merger of power with business, the oligarchic nature of the state, appropriation of a large part of financial, budget flows, corruption. Detection, by means of the system analysis, of the indicated problems, their diagnosis (establishment of the causes of occurrence), as well as the definition (at the conceptual level) of solutions to problems appears to be extremely important.

Economic reforms carried out in our country were mostly bureaucratic and formal. These reforms hid the country's plunder, theft of its assets, and the national wealth of the country. Meanwhile, in the textbooks on both administrative law and public administration, there are practically no issues about the administrative (administrative-legal) problems. Nobody speaks about the analysis of these problems, the development of ways, concrete

${ }^{17}$ Yuldashev, Smokovich (2019). 
measures for their solution. Reasons for the emergence of corruption (theft from the budget, appropriation of profits of state enterprises) is a "human factor" - the sinful nature of man, as well as the absence of a system of checks and balances, which should be embedded in the organization of management of the economy, its branches. In order to eliminate this reason, replace central executive authorities, a project - a system of organizational models for the coordination of economic activities of enterprises of the relevant branches of economic management of them, has been developed.

Introduction of the author's project will solve the existing managerial problems in the country's economy, ensure a sharp increase in the welfare of ordinary citizens, significant economic growth; stop theft of budget flows, separate business from power and, consequently, change the oligarchic nature of the state. Moreover, this is the way to achieve real independence, renewal of state sovereignty, redemption of lost territories, including the Crimea.

\section{References}

Constitution Ukraine. (1996). Retrieved January 9, 2020, from https://zakon.rada.gov.ua/ laws/show/254\%D0\%BA/96-\%D0\%B2\%D1\%80.

Drachkovich, M. V. (2019). On the Sources of Crisis in South Eastern Europe Societies. Sotsiologicheskie issledovaniya. Russian Academy of Science, 3, 145-149. DOI: 10.31857/ S013216250004287-8.

Heitz, V. M. (2009). The Socio-Economic Situation of Ukraine: Implications for the People and the State: A National Report. Kyiv: Educational Center of the National Library of Ukraine.

Kant, I. Critique of Pure Reason. The translation of N. Lossky is corrected and edited by Ts. Arzakanyan and M. Itkin. Notes by Ts. Arzakanyan. M.: Thought, 1994. Retrieved January, 10, 2020, from http://www.psylib.ukrweb.net/books/kanti02/index.htm.

Law of Ukraine. (2014). About Prevention of Corruption. Retrieved January 9, 2020, from https://zakon.rada.gov.ua/laws/show/1700-18.

Law of Ukraine. (2014). Inet of Ministers of Ukraine. Retrieved January 9, 2020, from https://zakon.rada.gov.ua/laws/show/794-18.

Lipinsky, D. A., Musatkina, A. A. (2019). Problems of compliance of Russian anticorruption legislation with international corruption standards. Vestnik of Saint Petersburg University. Law, 10(4), 673-690.

Mirror of the Week Ukraine (2011, September 9). Inability of the authorities to form a constructive transformation strategy leads to its hopelessness. Retrieved January 18, 2020, from https://dt.ua/ECONOMICS/anatoliy_galchinskiy_nespromozhnist_vladi_sformuvati _konstruktivnu_strategiyu_peretvoren_zumovlyue_y.html.

Okhrymenko, O. (2016). Antifashist. Information Agency. (2016, May 17). Ukrainian Economist: Ukraine needs 180 years in order to reach the level of 2013. Retrieved January 10, 2020, from http://antifashist.online/item/ukrainskij-ekonomist-ukraine-nuzhno-180let-chtoby-dostich-urovnya-2013-goda.html. 
Paris Guardian. (2017, December 21). U.S. concerned over pervasive high-level corruption in Ukraine's oil \& gas state agencies. Retrieved January 9, 2020, from https://www.parisguardian.com/newsr/8504.

Pecaric, M. (2019). The Centre of Government as the Coordination Point for the Implementation of General Legal Rules. DANUBE: Law, Economics and Social Issues Review, 10(3), 241-265. DOI: 10.2478/danb-2019-0013.

Valevsky, O. L. (2011). Analysis of the causes of failure of reforms in Ukraine. Governmental Management: Theory and Practice. Retrieved January 10, 2020, from http://academy.gov.ua/ej/ej14/txts/Valevskiy.pdf.

Valevsky, O. L. (2013). Cultural policy as creating modernization archetypes of the Ukrainian society. Public management: theory and practice: the collection of scientific works of the Association of Doctors of Sciences on Public Administration. Kh.: Publ. House "DokNaukDerzhUpr". Special Issue, 100-107.

Wschodnik. pl. (2017, December 21). The US is concerned about the high level of widespread corruption in the oil and gas state institutions of Ukraine. Retrieved January 9, 2020, from https://wschodnik.pl/publicystyka/item/14883-usa-sa-zaniepokojone-wysokim-poziomem-powszechnej-korupcji-w-ukrainskich-instytucjach-panstwowych-zwiazanych-z-ropa-naftowa-i-gazem.html.

Yuldashev, O. H, Smokovich M., Yuldashev O. O, Yuldashev S. O. (2019). Innovation and investment anti-corruption mechanism for economic development. Bulletin of Taras Shevchenko Kyiv National University, 4(87), 46-54. 